\title{
Pine Needle Water Extracts as Potential Abortive Agents in Gestating Cow Diets
}

\section{W. MAJAK, D. E. WALDERN, AND A. MCLEAN}

Highlight: A number of bovine abortions were reported during warm spells of the winter of 1974 in the southern interior of British Columbia. Observers speculated that the frequent thawing periods produced a run-off which extracted and accumulated abortive agents from the pine needle litter. In a test of this hypothesis, five pregnant cows each consumed extract from 200 to $300 \mathrm{~kg}$ ponderosa pine needles during their last trimester. No pre-partum effects were observed and five normal calves were delivered.

Authors are plant biochemist, animal nutritionist, and range ecologist, respectively, Research Station, Agriculture Canada, Kamloops, British Columbia, Canada.

The report is contribution no. 264, Research Station, Agriculture Canada, Kamloops, British Columbia

Manuscript received January 15, 1977
Abortions in cattle induced by yellow pine (Pinus ponderosa) needles have been reported by numerous investigators in western Canada and the United States (MacDonald 1952; Stevenson et al. 1972; Kamstra 1975). Veterinarians and ranchers in the southern interior of British Columbia reported a rash of bovine abortions during the warm spells of the winter of 1974. However, the incidents occurred in ponderosa pine stands devoid of slash or fresh windfall foliage. Observers speculated that the frequent thawing periods produced a run-off which extracted and accumulated abortive agents from the pine needle litter. It appeared that abortions occurred when 
cows drank from pools containing leached components of dried pine needles.

To test this hypothesis, in 1975 the drinking water of five pregnant Jersey cows in their last trimester was replaced by a water extract of pine needles; the needles had been collected from the litter of a ponderosa pine savannah range. The extract was produced in batches by soaking approximately $40-\mathrm{kg}$ needles in 400 liters water for one week at $7^{\circ} \mathrm{C}$. The foamy, straw-coloured extract was consumed by each animal at the rate of 20 to $30 \mathrm{~kg} /$ day with hay rations at $7 \mathrm{~kg} /$ day and bimonthly salt and mineral supplements for the remainder of the pregnancy. During this period, the total liquid consumption for each cow represented the extract of 200 to $300 \mathrm{~kg}$ pine needles. No prepartum effects were observed and five normal calves were delivered. All survived with the exception of one which died at seven days, and in this case, the cause of death was histopathologically diagnosed as pneumonia.

Chow et al. (1972) reported that an aqueous fraction of ponderosa pine needles could disrupt fetal development in mice. Subsequent experiments by the authors (Chow et al. 1974) however, failed to induce reproductive failure. Similarly, inconsistent results were obtained at the Agriculture Canada Research Station, Kamloops (Nicholson, 1954; Agriculture Canada Annual Reports 1955 to 1959) when abortion trials with cows were repeated following the initial study by MacDonald (1952). In 1953, for example, one cow in the control group of six aborted, while only two cows of the 12 consuming pine needles aborted. MacDonald (1952), on the other hand, had reported a reproductive failure rate of $75 \%$ under similar experimental conditions. The studies were repeated again during the winters of 1958 and 1959. The former trial yielded a reproductive failure rate of $50 \%$, but all the calves survived in the final experiment. It should also be noted that no abortions were recorded in two analogous studies with lodgepole pine (Pinus contorta) needles (Nicholson 1954; Agriculture Canada Annual Report 1957).

Chow et al. (1974) were able to obtain reproducible results with mice, however, when the aqueous pine needle extracts were infected with a fungus occurring on ponderosa pine needles. The authors suggested, therefore, that toxic fungal metabolites derived from plant constituents could be more directly involved in pine needle abortion. Whether the variability in the earlier experiments at Kamloops and the recent results with pine needle litter are related to the presence or absence of a mycotoxin(s) remains to be seen but the fungal parameter should be considered in further research on pine needle abortion.

\section{Literature Cited}

Agriculture Canada Annual Reports. 1955-59. Animal Husbandry Division, Kamloops, British Columbia.

Chow, F. C., K. J. Hanson, D. W. Hamar, and R. H. Udall. 1972. Reproductive failure of mice caused by pine needle ingestion. J. Repro. Fert. 30:169-172.

Chow, F. C., D. W. Hamar, and R. H. Udall. 1974. Mycotoxic effect on fetal development: pine needle abortion in mice. J. Repro. Fert. 40:203-204.

Kamstra, L. D. 1975. Crops and Soils Magazine. June-July, p. 25-26.

MacDonald, M. A. 1952. Pine needle abortion in range beef caule. J. Range Manage. 5:150-155.

Nicholson, H. H. 1954. Range Experiment Station, Kamloops, B.C. Progress Report 1947-53. p. 42-46. Information Canada, Ottawa.

Stevenson, A. H., L. F. James, and J. W. Call. 1972. Pine needle (Pinus ponderosa)-induced abortion in range cattle. Cornell Vet. 52:519-524. 
cows drank from pools containing leached components of dried pine needles.

To test this hypothesis, in 1975 the drinking water of five pregnant Jersey cows in their last trimester was replaced by a water extract of pine needles; the needles had been collected from the litter of a ponderosa pine savannah range. The extract was produced in batches by soaking approximately $40-\mathrm{kg}$ needles in 400 liters water for one week at $7^{\circ} \mathrm{C}$. The foamy, straw-coloured extract was consumed by each animal at the rate of 20 to $30 \mathrm{~kg} /$ day with hay rations at $7 \mathrm{~kg} / \mathrm{day}$ and bimonthly salt and mineral supplements for the remainder of the pregnancy. During this period, the total liquid consumption for each cow represented the extract of 200 to $300 \mathrm{~kg}$ pine needles. No prepartum effects were observed and five normal calves were delivered. All survived with the exception of one which died at seven days, and in this case, the cause of death was histopathologically diagnosed as pneumonia.

Cnow et al. (1972) reported that an aqueous fraction of ponderosa pine needles could disrupt fetal development in mice. Subsequent experiments by the authors (Chow et al. 1974) however, failed to induce reproductive failure. Similarly, inconsistent results were obtained at the Agriculture Canada Research Station, Kamloops (Nicholson, 1954; Agriculture Canada Annual Reports 1955 to 1959) when abortion trials with cows were repeated following the initial study by MacDonald (1952). In 1953, for example, one cow in the control group of six aborted, while only two cows of the 12 consuming pine needles aborted. MacDonald (1952), on the other hand, had reported a reproductive failure rate of $75 \%$ under similar experimental conditions. The studies were repeated again during the winters of 1958 and 1959. The former trial yielded a reproductive failure rate of $50 \%$, but all the calves survived in the final experiment. It should also be noted that no abortions were recorded in two analogous studies with kdgepole pine (Pinus contorta) needles (Nicholson 1954: Agriculture Canada Annual Report 1957).

Chow et al. (1974) were able to obtain reproducible results with mice, however, when the aqueous pine needle extracts were infected with a fungus occurring on ponderosa pine needles. The authors suggested, therefore, that toxic fungal metabolites derived from plant oonstituents could be more directly involved in pine needle abortion. Whether the variability in the earlier experiments at Kamloops and the recent results with pine needle litter are related to the presence or absence of a mycotoxin(s) remains to be seen but the fungal parameter should be considered in further research on pine needle abortion.

\section{Literature Cited}

Agriculture Canada Annual Reports. 1955-59. Animal Husbandry Division, Kamloops, British Columbia.

Chow, F. C., K. J. Hanson, D. W. Hamar, and R. H. Udall. 1972. Reproductive failure of mice caused by pine needle ingestion. J. Repro. Fert. 30:169-172.

Chow, F. C., D. W. Hamar, and R. H. Udall. 1974. Mycotoxic effect on fetal development: pine needle abortion in mice. J. Repro. Fert. 40:203-204

Kamstra, L. D. 1975. Crops and Soils Magazine. June-July, p. 25-26

MacDonald, M. A. 1952. Pine needle abortion in range beef cattle. J. Range Manage. 5:150-155.

Nicholson, H. H. 1954. Range Experiment Station, Kamloops, B.C. Progress Report 1947-53. p. 42-46. Information Canada, Ottawa.

Stevenson, A. H., L. F. James, and J. W. Call. 1972. Pine needle (Pinus ponderosa)-induced abortion in range cattle. Comell Vet. 52:519-524 